\title{
Developing an Android-based bilingual e-glossary application of English for Specific Purposes (ESP)
}

\author{
Siti Rohani ${ }^{a, 1^{*}}$, Achmad Suyono ${ }^{\mathrm{b}, 2 \text {, }}$ \\ ${ }^{a, b}$ State Polythecnic of Malang, Jl. Soekarno-Hatta No. 09, Malang 65141, Indonesia \\ siti.rohani@polinema.ac.id ${ }^{1, *}$, achmad.suyono@polinema.ac.id ${ }^{2}$ \\ *corresponding author
}

\section{ARTICLE INFO}

\section{Article history}

Received 26 November 2021

Revised 15 December 2021

Accepted 30 December 2021

Keywords

bilingual

glossary

android application

English for Specific Purposes

\section{ABSTRACT}

One effort considered quite effective in assisting vocabulary mastery and facilitating understanding of English texts is the provision of a bilingual glossary (English-Indonesian). This glossary becomes more essential especially for non-English Department students because basically English for Specific Purposes has a higher level of difficulty than general English. This study was a design and development research, with a product cluster and research tool. There were four main stages undergone, namely preliminary study, product development, expert validation, and field-testing. The research subjects were students and lecturers in seven departments of both commerce and engineering schools at State Polytechnic of Malang. Instruments of data collection used were questionnaires, interviews, and focused group discussion. The output of the study is an android application of bilingual E-Glossary of English for Specific Purposes. There were seven fields of glossary, each of which consists of vocabulary in English, the translation or description in Indonesian language, along with example sentences in two languages. Pictures are also displayed for easy understanding of the vocabulary. Field testing proves that the E-Glossary application is quite effective in helping users in comprehending English texts better. The application is also considered attractive, easy to use, and easy to understand.

This is an open access article under the CC-BY-SA license.

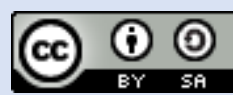

How to Cite: Rohani, S. \& Suyono, A. (2021). Developing an Android-based bilingual e-glossary application of English for Specific Purposes. English Language Teaching Educational Journal, 4(3), 225-234.

\section{Introduction}

In the current global era, there are almost no borders between one country and another. Likewise, education may be obtained in any country in the world. Now students can choose to study in Indonesia, Singapore, Malaysia, Australia, and even other countries, by utilizing various scholarships offered by universities, multinational companies, governments, or even with private funding. The opportunities to study abroad now are much more facilitated and publicized for all students around the world. Thus, international classes are available in most universities in Indonesia (Muttaqin, 2020).

The main medium in delivering learning materials and communication plays a very essential role in the current global era. In this case, English is recognized as one of the international languages used as a medium of communication in higher education internationalization in Indonesia, including for delivering learning materials (Simbolon, 2021). Many English textbooks are used as compulsory learning materials in all fields of study. In other words, English is the main communication medium in the current global era. 
Despite the prominent role of English that has been recognized as the international language and becomes the primary medium to master knowledge, students still encounter various challenges in mastering English. The main problem faced by students in mastering English is vocabulary while vocabulary is believed to be the most essential component of a language. Gebhard (2000) states that vocabulary building is one of the main problems faced in reading activities. Brown and Lee (2015) also confirmed that the lack of vocabulary mastery is the main obstacle in students' reading activities.

Vocabulary is believed as the bone of a body of language. Poor vocabulary mastery may communication breakdown and block the acquiring of knowledge. Nation (2013) elaborated the two factors leading to a communication's ineffectiveness: first, the learner does not have sufficient vocabulary mastery, and second, the learner does not know how to use the vocabulary in communication. Thus, attempts should be made in order to assist students to acquire better mastery of vocabulary.

While reading can improve vocabulary mastery, many students are weak or lacking in mastering vocabulary in reading activities. One effort that is considered quite effective in helping vocabulary mastery and facilitating understanding of English texts is the provision of a bilingual glossary (English-Indonesian Language). A lot of studies (eg., Cohen, Tracy, \& Cohen, 2017; Wolf, Kim, \& Kao, 2012) have demonstrated the importance of a glossary in helping students to attain successful learning. Therefore, glossary becomes more essential especially for non-English students as basically English for Specific Purposes has a higher level of difficulty than general English. Furthermore, learning process will be more effective by paying attention to the supporting factors such as learning methods or strategies; interesting, challenging, and motivating learning materials; and the use of appropriate learning media. All of those, surely, cannot be separated from the use of the latest technology.

Technologies, however, are changing rapidly and, as a result, changing how people work and interact in nearly every sector, including education. One consequence of this convergence of situations is a tension in training and education. On one hand, new technologies provide the ability to support highly personalized and learnercentered education. (Spector, 2015, p. 3)

Thus, the learning materials arrangement must be attempted to follow the most updated technology advancement.

Currently, the use of the latest technology in English learning is widely known and implemented, including the use of mobile phones. Research have been conducted to review or develop mobile phone-based English learning media (eg., Adlof et al., 2019; Ally \& Samaka, 2013; Cavus \& Ibrahim, 2009; Hao, Lee, Chen, \& Sim, 2019; Thornton \& Houser, 2005). In fact, Rohani, Suyono, and Rozi (2019) have developed an interactive mobile phone application for autonomous English learning with the components of reading, listening, writing, pronunciation, and vocabulary with the most outstanding effectiveness on the improvement of vocabulary mastery. This confirms the effective use of mobile phone as a medium of vocabulary learning. In different context of the vocabulary learning for senior high school students, Adlof et al. (2019) proved the effectiveness of a DictionarySquared research platform with a web-based vocabulary program that provides individualized vocabulary instruction. Furthermore, Cavus and Ibrahim (2009) also confirmed the effectiveness of a Mobile Learning Tool (MOLT) system in which students enjoyed and learned new words with the help of their mobile phones.

With the many research on the use of high technology, especially mobile phones in the learning of English, a few have been done regarding with the use of mobile phone to assist non-English department students to read English texts, in this sense is the use of mobile phone as a medium for a glossary. Research resulting in the development of glossary include those conducted by Cohen et al. (2017) and by Wolf et al. (2012). Only a few have been done in Indonesia while in fact, glossary in this sense is supposed to be bilingual, in English and in local language. Development research with the topic on designing dictionary or glossary for Indonesian students are only for certain departments; no research has been done to develop bilingual glossary for several departments in one mobile application. Therefore, it is prominent to develop an English-Indonesian glossary of English for Specific Purposes for Indonesian students. 
This study was done with the main aim to develop an android based bilingual E-Glossary in order to assist students, especially non-English Department students to comprehend English texts. The research was assisted by students in doing their final projects.

\subsection{Reading and Vocabulary Mastery}

In the current study, what is referred to be reading is not simply reading, but reading with comprehension. Therefore, when a student says he can read a written text but he does not understand the message, he is not really "reading" it. Reading here is not only decoding or translating written symbols into appropriate sounds, however, reading also involves several components: the reader, the text, and the reading activity itself.

Butler et al. (2010) describe vocabulary as "knowledge of words and their meanings". Vocabulary is also claimed to be "something that expands and it deepens over time'. Then, Saidbakhramovna, Valijonvna, and Sharofidinovna (2021) illustrate the important features of vocabulary in receiving knowledge in a foreign language; they emphasize the core hypothesis of vocabulary as well as several crucial strategies and vital techniques of mastering vocabulary.

Apart from grammar and pronunciation, vocabulary plays an important role in learning a foreign language because the meaning of new words is often emphasized either in books or in class (Alqahtani, 2015). Vocabulary is one component that connects speaking, writing, reading, and listening (Schmitt \& Schmitt, 2020).

Difficulties in reading can be caused by a variety of causes, one which is poor vocabulary. Readers with insufficient vocabulary knowledge will encounter difficulties in reading texts containing a lot of foreign terms. Gebhard (2000) states that "vocabulary development" is one of the problems faced by most English as a Foreign Language (EFL) teachers in teaching reading comprehension. He also discovered that students frequently asked their teachers how they could improve their vocabulary knowledge to cover their difficulties in reading texts.

In addition, (Brown \& Lee, 2015) mention one of the reasons why students frequently find the lack of vocabulary to be an obstacle to their reading activities. They further states that 'as a written language, reading usually uses more variety of lexical items than spoken conversational language' (Brown \& Lee, 2015, p. 400).

In this view, the critical importance of receptive vocabulary in developing or improving foreign language reading skills requires a stronger focus on the enrichment of receptive vocabulary itself. The correlation between receptive vocabulary and reading creates a cycle of interdependence between the two. When the learner's receptive vocabulary is improved, they will find it easier to read the text, resulting in richer input in the receptive vocabulary.

It is undeniable that the aspect of reading includes many aspects other than just vocabulary. As noted by Nation (2013), increasing a learner's vocabulary does not always imply a significant improvement in reading skills. However, vocabulary size proved to be the best predictor of reading comprehension. However, every increase in vocabulary size must be supported by many opportunities to utilize the vocabulary in reading activities in order to improve the foreign language competence in general.

In order to master a new language, second language learners need to know a very large number of words in the target language (Nation, 2013). When people have a large number of vocabularies in mind, they will select words easily on certain situations. Without having much vocabulary, it is hard to write, speak and understand the target language. Thus, enriching vocabulary will be of great benefit in learning a new language, including English. Vocabulary is also the main requirement in learning English as a Second Language (ESL) and learning English as a Foreign Language (EFL).

Vocabulary is the base of literacy, and teaching impacts vocabulary and reading comprehension. It is well documented that teaching vocabulary is better than no instruction at all even though this instruction barely contributes much to the number of words students have to accomplish. Vocabulary knowledge should also be seen as key to the improvement of reading skills; vocabulary improvement should be seen as both a cause and a consequence of reading ability. Thus, the discussion of vocabulary must be seen from its relation to reading improvement. 


\subsection{Dictionary}

Dictionary is an important tool in learning vocabulary and foreign languages, and a lot of information about words and their usage is displayed in a dictionary (Ali, 2012). A dictionary can be in monolingual, bilingual, or printed dictionary (Cohen et al., 2017). Al Bulushy (2012) states the variety of dictionary formats as printed dictionary, pocket electronic dictionary, dictionary program, online dictionary, and visual dictionary.

Using a dictionary while reading can help students understand the text and learn vocabulary and further can be used as a tool to find the true meaning of a word (Rohmatillah, 2016). A dictionary is also important for learning English as a foreign language, and, obviously, dictionary can be a tool for students to understand the true meaning of a word in a particular context.

\subsection{Glossary (Glossary)}

According to Cohen, Tracy, and Cohen (2017), "A glossary contains simplification of terms and phrases that are not related to content that is considered complex for students. This simplification includes clarification of complex sentences and synonyms or word definitions related to the context". A glossary can also contain a list of terms in one or more languages (Crabbe \& Heath, 2017).

Glossary and dictionary are different. The difference between a glossary and a dictionary is that the definitions given by the glossary are in context (Cohen et al., 2017). Glosses can usually be found at the end of a text or book in a glossary (Webb, 2010), yet in this study, glossaries are compiled and inputted into an Android application.

Glossaries can be found in a variety of formats, including paper-based glossaries, online-based glossaries, and computer programs. With technological advances, glossaries can also be accessed in mobile phone applications. In the current research, the developed glossary application was made for Android mobile phone.

Several studies have been regarding the implementation and effectiveness of glossaries and dictionary in assisting students in their learning. Wolf et al. (2012) confirmed the effectiveness of glossaries only for students or users who dealt with the field of study but not for users of different field of study; thus, glossaries are effective for those who have the content knowledge. Furthermore, Cohen et al. (2017) confirm the effectiveness and influence on validity of a computer-based pop-up English glossary accommodation for English learners. One development research on the topic of glossary and dictionary has been done by Ependi and Widayati (2014) who focused on the development of dictionary for Accountancy. Subhan (2014) also developed an application of dictionary in three languages (English-Japanese-Indonesian); he focused on the development of the program without emphasizing the content of the dictionary.

\section{Method}

The design of the current research was Design and Development Research (DDR) or also known as development research. The current DDR research is a systematic study of design, development, and evaluation processes to establish an empirical basis for the creation of instructional and noninstructional products and tools and new or enhanced models that govern their development (Richey \& Klein, 2014).

Out of the two clusters in DDR, the current research belonged to the product and tool research as the research was to develop and design a bilingual E-Glossary application, an Android-based brief dictionary or glossary of English - Indonesian Language for several fields of study, namely Business Administration, Accounting, Informatics, Civil Engineering, Mechanical Engineering, Electrical Engineering, and Chemical Engineering.

The current DDR research was carried out following four phases of development research, namely preliminary study, product development, expert validation, and field testing. In the preliminary study phase, questionnaires were distributed, interviews with students and non-English lecturers from several majors in State Polytechnic of Malang. The main data achieved were about the essential need to read English texts in each of their fields as well as the need for brief two-language dictionaries made specifically for each of their fields. Furthermore, respondents' preferences in using a dictionary or glossary in the form of books, computer programs, or Android applications were also explored. 
With the data achieved, the second phase, product development, of the research was carried out. In the second phase, the design and development of the bilingual E-Glossary application for non-English students of several major fields were carried out. The third phase was the expert validation, which was carried out by asking for validation from content and language experts. The last stage was the fieldtesting phase where the field test was carried out on the bilingual E-Glossary application that has been developed. The trial or field test was done by applying it in several majors at the State Polytechnic of Malang. During the product trial, observations, questionnaires distribution, and interviews with lecturers and students who used the application were also done. Finally, using the field-testing data, the bilingual E-Glossary application was revised. Revision was made for three times after returning the draft back to the expert validator.

The subjects of the research were students and lecturers of State Polytechnic of Malang. Several data collection instruments were used, namely in-depth interview (preliminary study, field testing), Focus Group Discussion or FGD (preliminary study, field testing), and Questionnaire (preliminary study, expert validation, field testing). The respondents filled out the questionnaires for the preliminary study and field-testing phases. Some of them also participated in focus group discussions. Furthermore, for the expert validation phase, expert respondents were from each field of study while the language expert or translators were lecturers at the English Department of State Polytechnic of Malang who were also professional translators. Experts were invited to fill out questionnaires and participate in interviews.

\section{Findings and Discussion}

\subsection{Findings}

The preliminary study was begun by distributing the questionnaires to the respondents -92 students and lecturers of some departments of State Polytechnic of Malang. The questions in the questionnaire focused on the respondents' needs for the Android-based glossary application. There were seven simple questions to confirm the need to develop an English for Specific Purpose (ESP) glossary Android application.

From the close-ended questionnaire of 1-6 Likert scales, it was identified several findings. Most of the respondents often read English texts (3.62). They also often encountered problems (3.87) in understanding the text, both vocabulary problems (3.71) and grammar problems (3.96). Almost all respondents agreed that the glossary could help them to understand the English text they read (4.71). Furthermore, the development of a bilingual glossary in one Android application was considered to be very helpful for the respondents to understand the English text they read, with an index of 5.57. Therefore, it can be concluded that the development of a bilingual glossary in one Android application was very necessary.

In the design and development phase, several stages were carried out, namely designing the Android-based application, selecting the content or glossaries to be included in the application, translating the vocabularies and sentences, entering the data into the application program, and reviewing how the application that has been developed looked.

The first stage of the development phase was designing the Android-based application for the glossary. The mobile phone application was decided to use the Android system, not IOS, because there were more Android users than IOS users. The application program was submitted to the IT experts due to the limitations of the researchers in making application programs.

While waiting for the application program to be developed, the content of the application was prepared. It began with selecting the vocabularies to be entered into the glossary. Sources of the glossaries were textbooks and e-book websites. It was decided to collect 250 vocabularies from each field, making in total of 1750 vocabularies from 7 departments.

The vocabulary selection process from e-books was carried out using the AntCon program. The program could select the vocabularies that had the most frequent occurrences in each field. Then, the selected vocabularies were filtered and decided which ones were going to be included in the glossary. 
Table 1. Needs Analysis of the Development of a Bilingual E-Glossary

\begin{tabular}{|c|c|c|c|c|c|c|c|c|}
\hline \multirow[t]{2}{*}{ No } & \multirow[t]{2}{*}{ Questions } & \multicolumn{6}{|c|}{ Responses } & \multirow[t]{2}{*}{ Average } \\
\hline & & 1 & 2 & 3 & 4 & 5 & 6 & \\
\hline 1. & $\begin{array}{l}\text { How often do you read English } \\
\text { texts? }\end{array}$ & $\begin{array}{c}2 \\
(2 \%)\end{array}$ & $\begin{array}{c}15 \\
(16 \%)\end{array}$ & $\begin{array}{c}25 \\
(27 \%)\end{array}$ & $\begin{array}{c}23 \\
(25 \%)\end{array}$ & $\begin{array}{c}24 \\
(26 \%)\end{array}$ & $\begin{array}{c}3 \\
(3 \%)\end{array}$ & 3.62 \\
\hline 2. & $\begin{array}{l}\text { Do you encounter problems } \\
\text { while reading the English texts? }\end{array}$ & $\begin{array}{c}4 \\
(4 \%)\end{array}$ & $\begin{array}{c}9 \\
(10 \%)\end{array}$ & $\begin{array}{c}20 \\
(22 \%)\end{array}$ & $\begin{array}{c}26 \\
(28 \%)\end{array}$ & $\begin{array}{c}26 \\
(28 \%)\end{array}$ & $\begin{array}{c}7 \\
(8 \%)\end{array}$ & 3.87 \\
\hline 3. & $\begin{array}{l}\text { Do you often encounter } \\
\text { vocabulary problems in } \\
\text { comprehending the texts? }\end{array}$ & $\begin{array}{c}2 \\
(2 \%)\end{array}$ & $\begin{array}{c}7 \\
(8 \%)\end{array}$ & $\begin{array}{c}25 \\
(27 \%)\end{array}$ & $\begin{array}{c}36 \\
(39 \%)\end{array}$ & $\begin{array}{c}21 \\
(23 \%)\end{array}$ & $\begin{array}{c}1 \\
(1 \%)\end{array}$ & 3.71 \\
\hline 4. & $\begin{array}{l}\text { Do you encounter grammatical } \\
\text { problems while comprehending } \\
\text { the texts? }\end{array}$ & $\begin{array}{c}2 \\
(2 \%)\end{array}$ & $\begin{array}{c}8 \\
(9 \%)\end{array}$ & $\begin{array}{c}20 \\
(22 \%)\end{array}$ & $\begin{array}{c}32 \\
(35 \%)\end{array}$ & $\begin{array}{c}23 \\
(25 \%)\end{array}$ & $\begin{array}{c}7 \\
(8 \%)\end{array}$ & 3.96 \\
\hline 5. & $\begin{array}{l}\text { Do you think that a bilingual } \\
\text { glossary would help you to } \\
\text { comprehend the texts better? }\end{array}$ & $\begin{array}{c}4 \\
(4 \%)\end{array}$ & $\begin{array}{c}3 \\
(3 \%)\end{array}$ & $\begin{array}{c}10 \\
(11 \%)\end{array}$ & $\begin{array}{c}15 \\
(16 \%)\end{array}$ & $\begin{array}{c}34 \\
(37 \%)\end{array}$ & $\begin{array}{c}20 \\
(22 \%)\end{array}$ & 4.71 \\
\hline 6. & $\begin{array}{l}\text { Do you think that an android } \\
\text { based application of a bilingual } \\
\text { glossary would help you to } \\
\text { comprehend the texts better? }\end{array}$ & $\begin{array}{c}1 \\
(1 \%)\end{array}$ & $\begin{array}{c}1 \\
(1 \%)\end{array}$ & $\begin{array}{c}2 \\
(2 \%)\end{array}$ & $\begin{array}{c}4 \\
(4 \%)\end{array}$ & $\begin{array}{c}20 \\
(22 \%)\end{array}$ & $\begin{array}{c}64 \\
(70 \%)\end{array}$ & 5.57 \\
\hline
\end{tabular}

After selecting the 1,750 glossaries ( 250 glossaries from each field), a sentence example was made using the word. The vocabularies and sentence examples were then translated from English into Indonesian language. In addition to vocabulary, pictures were also attached to help users understand the vocabulary easily. After the collection of words and examples had been completely translated into the Indonesian language, all data were entered into an Excel file.

When all the data were ready, the application program was also ready to use. Thus, the next step was inputting the data from the Excel file into the application program. By using an existing Excel file, the step of inputting data into the program was easier to do as it was already in an Excel format.

The next phase was the expert validation in which the developed application was validated by content experts (from each department) and language experts (translators) who assessed the content and language of the developed application. The validation was carried out using a questionnaire with close and open-ended questions. Open-ended questions filled with opinions and inputs for application improvement.

The results of expert validation show a good result. The vocabularies and sentences were believed to be in accordance with the KBBI (Kamus Besar Bahasa Indonesia) with a score of 6 (scale 1-6). The spellings of the vocabularies and sentences were also found proper and correct. The sentences were written with the correct punctuation and capital letters. The choice of words in the examples of the translated sentences were considered good. The translation results were also considered good and correct. Sentence examples in English and the translations were considered easily can be understood. The illustrations were considered appropriate and quite helpful in understanding a new vocabulary. The developed E-Glossary application was considered attractive and easy to use. The size and type of font used in the application were also considered appropriate and easy to read.

One response and suggestion from the language expert is as below:

"It is an excellent work of the researcher, and I believe it will be very useful for those studying accounting. There are some points, however, that I'd like to recommend for the betterment of the work, especially in the field of example sentences: (a) There are some entries that need grammar check as they are not a complete sentence or their Subject-Verb do not agree (e.g. entries 31, 44, 47, 114, 195); (b) Some sentences use different Indonesian meaning in the example sentence (entries 38, 249); (c) I think it will be more contextual if the researcher considers the choice of examples to be in 
Indonesian setting, such as Rupiah or Jakarta in entries 33, 116, and 142; (d) I think it will be better to avoid stereotyping or bias in the example sentence such as accountant and fraud in entry 7. Nevertheless, I really appreciate such hard work of developing this glossary!"

In the expert validation phase, interviews with linguists and lecturers as experts were also conducted to get inputs to improve the E-Glossary application. The results of the interviews provided some inputs which were then applied in the application revision. The lecturers as experts stated some vocabularies were considered hard to be understood. The linguists also stated that the translation of some vocabularies was also considered to need revisions. With all the achieved inputs, a revision for the content was carried out, namely a review of vocabulary understanding and its translation into Indonesian language.

The last phase of the research was field testing. All questions in the questionnaire were answered by respondents and resulted in an average of above 5 (scale 1-6), which means that the developed application was considered good. Only one item about the number of vocabularies in each field in the application was considered lacking. The number of 1,750 vocabularies was considered quite good, but it still needed additional vocabularies to make it better.

Table 2. Responses on the Use of the Developed Bilingual E-Glossary

\begin{tabular}{|c|c|c|c|c|c|c|c|c|}
\hline \multirow[t]{2}{*}{ No } & \multirow[t]{2}{*}{ Criteria } & \multicolumn{6}{|c|}{ Responses } & \multirow[t]{2}{*}{ Average } \\
\hline & & 1 & 2 & 3 & 4 & 5 & 6 & \\
\hline 1. & $\begin{array}{l}\text { The number of vocabularies } \\
\text { in the glossary is sufficient. }\end{array}$ & $\begin{array}{c}1 \\
(3 \%)\end{array}$ & $\begin{array}{c}0 \\
(0 \%)\end{array}$ & $\begin{array}{c}2 \\
(6 \%)\end{array}$ & $\begin{array}{c}5 \\
(15 \%)\end{array}$ & $\begin{array}{c}16 \\
(47 \%)\end{array}$ & $\begin{array}{c}10 \\
(29 \%)\end{array}$ & 4.91 \\
\hline 2. & $\begin{array}{l}\text { The results of the } \\
\text { translation are easy to } \\
\text { understand. }\end{array}$ & $\begin{array}{c}0 \\
(0 \%)\end{array}$ & $\begin{array}{c}0 \\
(0 \%)\end{array}$ & $\begin{array}{c}1 \\
(3 \%)\end{array}$ & $\begin{array}{c}5 \\
(15 \%)\end{array}$ & $\begin{array}{c}17 \\
(50 \%)\end{array}$ & $\begin{array}{c}11 \\
(32 \%)\end{array}$ & 5.11 \\
\hline 3. & $\begin{array}{l}\text { The translation of } \\
\text { vocabularies in Indonesian } \\
\text { is easy to understand. }\end{array}$ & $\begin{array}{c}0 \\
(0 \%)\end{array}$ & $\begin{array}{c}0 \\
(0 \%)\end{array}$ & $\begin{array}{c}2 \\
(6 \%)\end{array}$ & $\begin{array}{c}3 \\
(9 \%)\end{array}$ & $\begin{array}{c}19 \\
(56 \%)\end{array}$ & $\begin{array}{c}10 \\
(29 \%)\end{array}$ & 5.08 \\
\hline 4. & $\begin{array}{l}\text { The translation of example } \\
\text { sentences in Indonesian is } \\
\text { easy to understand. }\end{array}$ & $\begin{array}{c}0 \\
(0 \%)\end{array}$ & $\begin{array}{c}0 \\
(0 \%)\end{array}$ & $\begin{array}{c}0 \\
(0 \%)\end{array}$ & $\begin{array}{c}6 \\
(18 \%)\end{array}$ & $\begin{array}{c}19 \\
(56 \%)\end{array}$ & $\begin{array}{c}9 \\
(26 \%)\end{array}$ & 5.08 \\
\hline 5. & $\begin{array}{l}\text { The application's design is } \\
\text { interesting. }\end{array}$ & $\begin{array}{c}0 \\
(0 \%)\end{array}$ & $\begin{array}{c}0 \\
(0 \%)\end{array}$ & $\begin{array}{c}3 \\
(9 \%)\end{array}$ & $\begin{array}{c}6 \\
(18 \%)\end{array}$ & $\begin{array}{c}12 \\
(35 \%)\end{array}$ & $\begin{array}{c}13 \\
(38 \%)\end{array}$ & 5.02 \\
\hline 6. & $\begin{array}{l}\text { The application is easy to } \\
\text { use. }\end{array}$ & $\begin{array}{c}0 \\
(0 \%)\end{array}$ & $\begin{array}{c}0 \\
(0 \%)\end{array}$ & $\begin{array}{c}0 \\
(0 \%)\end{array}$ & $\begin{array}{c}5 \\
(15 \%)\end{array}$ & $\begin{array}{c}13 \\
(38 \%)\end{array}$ & $\begin{array}{c}16 \\
(47 \%)\end{array}$ & 5.32 \\
\hline 7. & $\begin{array}{l}\text { The font and size of the } \\
\text { contents are easy to read. }\end{array}$ & $\begin{array}{c}0 \\
(0 \%)\end{array}$ & $\begin{array}{c}0 \\
(0 \%)\end{array}$ & $\begin{array}{c}2 \\
(6 \%)\end{array}$ & $\begin{array}{c}7 \\
(21 \%)\end{array}$ & $\begin{array}{c}10 \\
(29 \%)\end{array}$ & $\begin{array}{c}15 \\
(44 \%)\end{array}$ & 5.11 \\
\hline 8. & $\begin{array}{l}\text { The images are clear and } \\
\text { proper. }\end{array}$ & $\begin{array}{c}0 \\
(0 \%)\end{array}$ & $\begin{array}{c}0 \\
(0 \%)\end{array}$ & $\begin{array}{c}1 \\
(3 \%)\end{array}$ & $\begin{array}{c}6 \\
(18 \%)\end{array}$ & $\begin{array}{c}15 \\
(44 \%)\end{array}$ & $\begin{array}{c}12 \\
(35 \%)\end{array}$ & 5.11 \\
\hline 9. & $\begin{array}{l}\text { The vocabulary in the } \\
\text { Bilingual Glossary } \\
\text { Application is easy to find. }\end{array}$ & $\begin{array}{c}0 \\
(0 \%)\end{array}$ & $\begin{array}{c}0 \\
(0 \%)\end{array}$ & $\begin{array}{c}0 \\
(0 \%)\end{array}$ & $\begin{array}{c}11 \\
(32 \%)\end{array}$ & $\begin{array}{c}11 \\
(32 \%)\end{array}$ & $\begin{array}{c}12 \\
(34 \%)\end{array}$ & 5.02 \\
\hline 10. & $\begin{array}{l}\text { Bilingual Glossary } \\
\text { Applications can assist you } \\
\text { in understanding English } \\
\text { texts. }\end{array}$ & $\begin{array}{c}0 \\
(0 \%)\end{array}$ & $\begin{array}{c}0 \\
(0 \%)\end{array}$ & $\begin{array}{c}1 \\
(3 \%)\end{array}$ & $\begin{array}{c}3 \\
(9 \%)\end{array}$ & $\begin{array}{c}18 \\
(54 \%)\end{array}$ & $\begin{array}{c}12 \\
(34 \%)\end{array}$ & 5.20 \\
\hline
\end{tabular}

The respondents who used the E-Glossary application considered the translation of vocabularies into the Indonesian language were quite easy to understand, including the use of the vocabulary in the example sentences. The application design was also considered attractive and easy to use. The font size and type used was easy to read. The use of the pictures was considered quite helpful. The 'find' feature in the application was also considered to be quite helpful in finding a new vocabulary in the application. Finally, the application was considered quite effective in helping users to understand English texts better. 


\subsection{Discussion}

The main result of the DDR research was a bilingual E-Glossary application which was developed to help students, especially non-English Department students to read and understand English texts well. The responses obtained from the field-testing phase showed the effectiveness of the application in helping the students to understand English texts. The finding is in line with several previous studies that have proven the effectiveness of mobile phone electronic learning media (eg. Basoglu \& Akdemir, 2010; Golonka, Bowles, Frank, Richardson, \& Freynik, 2014; Hamdani, 2013; Rohani et al., 2019).

The choice of making use of mobile phone is basically rooted from the fact that mobile phone is the most used tool to access information, including education media. The fastest growing web community is mobile visitors who browse web pages or retrieve web information using a cell phone over a wireless network (Chen \& Chung, 2008). Likewise, the development of educational technology lately tends to be mobilized, portable, and personal. This trend has caused the form of learning to change from traditional classroom learning to electronic learning.

Accommodating students' favored learning medium is one of the strategies to improve students' motivation to learn which later can assist the attainment of the learning goals. The use of technology in this sense is also the one mostly preferred by students. In the current study, when students find ease in comprehending English texts by using the android-based E-glossary, their motivation to read increase, and therefore, the process of comprehending texts becomes smoother and learning goals are attained. This is to confirm claims made by Fox (2014) who reveal the effectiveness of technology in increasing students' motivation to read and write. This is also in line with research findings by Hao et al. (2019) that the use of mobile application lead to students' positive attitude toward the learning of English.

Understanding and comprehending a new concept can be problematic, especially when it is an abstract concept. In the current study, all glossaries put in the application are aided by contextual examples; new vocabularies are put in sentences both in English and Indonesian language. Contextuality in this case is also supported by pictures. Such an arrangement is aimed to provide more ease in using the application. Abstract learning can be made easier by providing more "contextual" examples to the concept (Bernat \& Mueller, 2014). With contextual examples, then, knowledge formation can occur more easily.

\section{Conclusion}

The final aim of the current research was to develop a bilingual E-Glossary application for the Business Administration and Accounting Majors. The final product was an Android-based application called "POLINEMA Bilingual E-Glossary". The bilingual E-Glossary application contained the terms used in the fields of Business Administration and Accounting in English, the translations of those terms in the Indonesian Language, examples of the terms in English sentences along with the translations, as well as the pictures for each term. The expected significance of the DDR research was to assist users in understanding English texts better.

In carrying out the current research, there were four phases; preliminary study, product development, expert validation, and field-testing phase. In the preliminary study phase, the researcher identified that most of the students and lecturers had difficulties in understanding English texts, especially in terms of vocabulary and grammar. From the interviews regarding the problems faced by the students in classes (especially in international classes), they admitted that they still have difficulties understanding English material. Through a questionnaire, the students agreed that a bilingual EGlossary should be developed to assist them in understanding English texts.

After finding those problems, a bilingual E-Glossary application was developed as the second phase of the research that was the design and development phase. Furthermore, the developed bilingual E-Glossary application had been validated by linguists and lecturers as experts. In the third phase, revisions were made based on the inputs from those experts. Finally, the bilingual E-Glossary application was ready to be field-tested by the users and their opinions were recorded using a questionnaire. From the field-testing phase, it was found that the bilingual E-Glossary application was considered attractive, easy to use, and could help them understand English texts. 


\section{Acknowledgment}

This research was completed with the assistance of several students doing their final projects. Our gratefulness goes to them, Nurul Kharomah, Fauzi Riyanto, Alessa Salsabila, Ikhsanul Mu'izzaddin, Aldino, and Nadhif

\section{Declarations}

Author contribution

Funding statement

Conflict of interest

Additional information : No additional information is available for this paper

\section{REFERENCES}

Adlof, S. M., Baron, L. S., Scoggins, J., Kapelner, A., McKeown, M. G., Perfetti, C. A., . . Petscher, Y. (2019). Accelerating Adolescent Vocabulary Growth: Development of an Individualized, Web-Based, Vocabulary Instruction Program. Language, Speech, and Hearing Services in Schools, 50(4), 579-595. https://doi.org/10.1044/2019_LSHSS-VOIA-18-0143

Al Bulushy, Z. (2012). Paper Dictionary or Electronic One. Developing Teachers. com.

Ali, H. (2012). Monolingual dictionary use in an EFL context. English Language Teaching, 5(7), 2-7. https://doi.org/10.5539/elt.v5n7p2

Ally, M., \& Samaka, M. (2013). Open education resources and mobile technology to narrow the learning divide. 2013, 14(2), 14. https://doi.org/10.19173/irrodl.v14i2.1530

Alqahtani, M. (2015). The importance of vocabulary in language learning and how to be taught. International Journal of Teaching And Education, 3(3), 21-34. https://doi.org/10.20472/TE.2015.3.3.002

Basoglu, E. B., \& Akdemir, O. (2010). A comparison of undergraduate students' English vocabulary learning: Using mobile phones and flash cards. Turkish Online Journal of Educational Technology - TOJET, 9(7), $1-7$.

Bernat, C., \& Mueller, R. J. (2014). individualized learning with technology: Meeting the needs of high school students. Plymouth: Rowman \& Littlefield Education.

Brown, H. D., \& Lee, H. (2015). Teaching by principles:an Interactive approach to language pedagogy. New York: Pearson Education. Inc.

Butler, S., Urrutia, K., Buenger, A., Gonzalez, N., Hunt, M., \& Eisenhart, C. (2010). A review of the current research on vocabulary instruction. National Reading Technical Assistance Center, RMC Research Corporation, 1 .

Cavus, N., \& Ibrahim, D. (2009). m-Learning: An experiment in using SMS to support learning new English language words. British Journal of Educational Technology, 40(1), 78-91. https://doi.org/10.1111/j.1467-8535.2007.00801.x

Chen, C.-M., \& Chung, C.-J. (2008). Personalized mobile English vocabulary learning system based on item response theory and learning memory cycle. Computers \& Education, 51(2), 624-645. https://doi.org/10.1016/j.compedu.2007.06.011

Cohen, D., Tracy, R., \& Cohen, J. (2017). On the Effectiveness of Pop-Up English Language Glossary Accommodations for EL Students in Large-Scale Assessments. Applied Measurement in Education, 30(4), 259-272. https://doi.org/10.1080/08957347.2017.1353986

Crabbe, S., \& Heath, D. (2017). Creating a translation glossary using free software: A study of its feasibility with Japanese source text. International Journal of English Language and Translation Studies, 5(3), 151160.

Ependi, U., \& Widayati, Q. (2014). Rancang bangun aplikasi kamus istilah akuntansi pada smartphone dengan metode extreme programming Paper presented at the Seminar Nasional Teknologi Informasi dan Multimedia, STMIK AMIKOM Yogyakarta. 
Fox, L. C. C. (2014). Effects of technology on literacy skills and motivation to read and write. (Master). Suny Brockport, Retrieved from http://digitalcommons.brockport.edu/ehd_theses/522

Gebhard, J. (2000). Teaching English as a foreign language. Michigan: Michigan University Press.

Golonka, E. M., Bowles, A. R., Frank, V. M., Richardson, D. L., \& Freynik, S. (2014). Technologies for foreign language learning: a review of technology types and their effectiveness. Computer Assisted Language Learning, 27(1), 70-105. https://doi.org/10.1080/09588221.2012.700315

Hamdani, D. S. A. (2013). Mobile Learning: A Good Practice. Procedia - Social and Behavioral Sciences, 103, 665-674. https://doi.org/10.1016/j.sbspro.2013.10.386

Hao, Y., Lee, K. S., Chen, S.-T., \& Sim, S. C. (2019). An evaluative study of a mobile application for middle school students struggling with English vocabulary learning. Computers in Human Behavior, 95, 208216. https://doi.org/10.1016/j.chb.2018.10.013

Muttaqin, S. (2020). Higher Education Internationalization: A Brief Look at International Classes and English Medium Instruction (EMI) Policy at Universities in Indonesia. Paper presented at the 37th International Conference on English Teaching and Learning, Ming Chuan University.

Nation, I. (2013). Learning vocabulary in another language. Cambridge: Cambridge University Press. https://doi.org/10.1017/CBO9781139858656

Richey, R. C., \& Klein, J. D. (2014). Design and development research. In J. M. Spector, M. D. Merrill, J. Elen, \& M. J. Bishop (Eds.), Handbook of Research on Educational Communications and Technology (pp. 141-150). New York, NY: Springer New York. https://doi.org/10.4324/9780203826034

Rohani, S., Suyono, A., \& Rozi, I. (2019). Designing a mobile application for autonomous learning of English. https://doi.org/10.4108/eai.23-3-2019.2284960

Rohmatillah, R. (2016). Dictionary usage in English language learning. English Education: Jurnal Tadris Bahasa Inggris, 9(1), 186-197.

Saidbakhramovna, A. F., Valijonvna, R. N., \& Sharofidinovna, K. D. (2021). The method of educating vocabulary in a foreign language or target language. Linguistics and Culture Review, 5(S1), 1649-1658. https://doi.org/10.21744/lingcure.v5nS1.1994

Schmitt, N., \& Schmitt, D. (2020). Vocabulary in language teaching. Cornwall, United Kingdom: Cambridge University Presss. https://doi.org/10.1017/9781108569057

Simbolon, N. E. (2021). English Medium Instruction (EMI) practice: Higher education internationalization in Indonesia. Englisia: Journal of Language, Education, and Humanities, 8(2). https://doi.org/10.22373/ej.v8i2.8961

Spector, J. M. (2015). Education, training, competencies, curricula and technology. In X. Ge, D. Ifenthaler, \& J. M. Spector (Eds.), Emerging Technologies for STEAM Education: Full STEAM Ahead (pp. 3-14). Cham: Springer International Publishing. https://doi.org/10.1007/978-3-319-02573-5_1

Subhan, A. (2014). Aplikasi Kamus Tiga Bahasa Berbasis Android. (Bachelor). Universitas Muhammadiyah Yogyakarta, Yogyakarta.

Thornton, P., \& Houser, C. (2005). Using mobile phones in English education in Japan. Journal of Computer Assisted Learning, 21(3), 217-228. https://doi.org/10.1111/j.1365-2729.2005.00129.x

Webb, S. (2010). Using glossaries to increase the lexical coverage of television programs. Reading in a Foreign Language, 22(1), 201-221.

Wolf, M. K., Kim, J., \& Kao, J. (2012). The effects of glossary and read-aloud accommodations on English language learners' performance on a Mathematics assessment. Applied Measurement in Education, 25(4), 347-374. https://doi.org/10.1080/08957347.2012.714693 